\title{
Empowerment of Women in Rural India through SHGs - A Step towards Financial Inclusion
}

\author{
Sonjuhi Akhil Succena
}

\begin{abstract}
Empowerment is a powerful word and should hold the weight it carries. When we talk about 'women empowerment', it seems to lose half of its weight as against powerful lobby of men who are responsible to encourage it. The Self help group or SHGs and the credit linkage scheme for it, started as a pilot programme in 1992 . In the last 23 years it has not shown the results envisioned by the proposers. The intention is good but the tool needs more sharpening. Merely economic support is not enough to sustain such a model.

For women empowerment education is a pre-requisite to the success of this model. By education, we mean knowledge enhancement through school education, occupational and management skills. Women by nature have managerial skills which need to be harnessed. They have patience, vision and a planning instinct better than men.

Through this study we discuss, a statistical understanding of women empowerment in India and the Self Help Group (SHG) credit and savings programme, being enforced to achieve it. As a result, the need is felt for more Financial Institutions to join in such initiatives.
\end{abstract}

Index Terms-Financial inclusion, SHG, SHG credit bank linkage programme, women empowerment.

\section{LITERACY RATE IN RURAL INDIA}

Rural Indian women work almost 11 hours more than urban women and 12 hours more than urban men per week [1]. It has been observed that the core issues that would benefit the cause of women empowerment are education, increase in health and safety facilities and eradication of poverty. While India has grown in many fields since independence, we still have a concerning gap in the level of education between women and men. While $82.14 \%$ of adult men are educated, only $65.46 \%$ of adult women are known to be literate in India. $39 \%$ of the world's illiterate adults are found in India [2], the gender bias is observed in higher education, specialized professional trainings which hit women very hard in employment and attaining top leadership in any field.

For the well being of any country it is imperative that the health and safety concerns of women are addressed and actioned upon. However, the country still faces alarming concerns in the area of maternal healthcare. Eradication of poverty should be a national goal as important as the eradication of illiteracy. As it is due to poverty, that women are exploited as domestic helps. Poverty is a threat to peace in our nation

Manuscript received April 15, 2016; revised July 20, 2016.

The author is with the 2nd largest Bank, India (e-mail: succenasonjuhi@gmail.com).
As per the annual report 2013-14 data from the Ministry of Human Resource Development (HRD), Govt. of India, the drop-out rates of girls from classes 1 st to 10th still stands at $52.2 \%$ which is lower than the $71.5 \%$ in $2000-01$ [3]. The number, though daunting, has been reduced over the years. However, the quality of improvement is still debatable. A recent study by Prof Brij Kothari of Indian Institute of Management (IIM)-Ahmadabad reveals that the 260 million so-called 'literate' people, according to the census, in practice cannot read [4]. The literacy rate in India is highly exaggerated and based on the report by parents and not on proper evaluation of the children's ability to read and write.

\section{ISSUE OF WOMEN EMPOWERMENT}

Even when the government introduces plans, budgets, schemes to tackle the issues we still end up grasping at straws and are unable to provide effective outcomes. Enactment of the law from the side of the central/state/local governments for empowering of women cannot bring a group of empowered women in the true sense of the term 'empower' until we bring a change in women's mobility, social interaction and change in women's access and control over resources. Changes in women's control over decision making, providing education, establishing self employment and self help groups, fulfilling minimum needs like nutrition, health, sanitation, housing is very much needed in today's context. Moreover, the society should change its mentality towards the word women and encourage women to develop in their fields they are good at and make a career.

\section{SELF HELP GROUP-INITIATIVE IN RURAL WOMEN EMPOWERMENT}

Financial Inclusion is a hot topic for a country like India, dipping its toes in the global arena of World Economy. SHG microfinance is one of the useful channels of financial inclusion. The outcome from the SHGs is encouraging and is becoming the focus of implementation to reach out to the poor segment of society in rural India.

SHGs function on the basis of co-operative principles and provide a forum for members to extend support to each other. It is considered as a means of empowerment. SHGs organise very poor people who do not have access to financial system in the organised sector. In such groups, normal transparency and accountability are lacking.

India is an agrarian country and its female population constitutes a third of the total labour force. They form the backbone of the agricultural activities where most of the agriculture labour is women. SHGs are considered as one of 
the most significant tools for the economic empowerment of women

The objective of an SHG is to instill the habits of savings and banking in women and to facilitate credit options. It works to garner strength among the rural masses and ensure financial stability in women living below poverty line. In doing so, it also enhances their confidence and capabilities and encourages women to take the up the mantel of social responsibility and pave it forward to the next generation of women.

The SHG - Bank Linkage Programme is a major plank of strategy for delivering financial services to the poor in a sustainable manner. The search for such alternatives started with internal introspection regarding the innovations which the poor had been traditionally making, to meet their financial needs. It was observed that the poor tended to come together in a variety of informal ways for pooling their savings and dispensing small and unsecured loans at varying costs to group members on the basis of need.

\section{History OF SHG CREDIT BANK LinKAGE PROGRAMME}

The SHG-Bank Linkage Programme was started as an action research project in 1989 which was the offshoot of a National Bank for Agriculture and Rural Development (NABARD) initiative during 1987 through sanctioning of seed money assistance for experimenting Credit Management Groups [5].

The experiences of early efforts led to the approval of a pilot project by NABARD in 1992. The pilot project was designed as a partnership model between three agencies, viz., the SHGs, banks and NGOs. This was reviewed by a working group in 1995 that led to the evolution of a streamlined set of RBI approved guidelines to banks to enable SHGs to open bank accounts, based on a simple interest agreement. This was coupled with a commitment by NABARD to provide refinance and promotional support to banks for the SHG Bank Linkage Programme.

As per the Nabard annual report of 2014-15, as on 31 March 2014, there were more than 74.30 lakh savings-linked SHGs, covering over 9.7 crore poor households. The total savings of these SHGs with banks amounted to 9897.42 crore. The number of credit-linked SHGs under the programme was 41.97 lakh [6]. The $12^{\text {th }}$ Five year plan running for the current financial year, also targets the formation of 1.4 lakh Self Help groups under the National rural livelihood mission (NRLM)

SHGs exist to create a healthy and hopeful environment for people below poverty line and enable them to increase their income thereby improve their quality of life and status in society. It is the transition that is bringing the rural masses into the mainstream of society

As per the Status of Microfinance in India report of 2013-14 by NABARD, the number of saving linked SHGs now stands at 74.3 lakh with a membership of over 96.6 million poor households showing a marginal increase of $1.53 \%$ from the previous year 2012-13. The savings balance of these SHGs with banks, however, shot up by over $20 \%$ during the year (9897 crore in 2013-14 against 8217 crore in 2012-13).

The Government of India and various state Governments have been implementing various programmes for rural upliftment. However, rural poverty and unemployment still persist in the country. This problem is becoming severe and acute. Among the various programmes "Swarna Jayanti Gram Swarojgar Yojana" (SGSY) is an important one. The Scheme was funded by the Centre and the States in the ratio of 75:25 [7]

The objective of SGSY is to bring the poor families (Swarozgaris) above the poverty line by ensuring appreciable sustained income over period of time. This objective is to be achieved by inter alia organising the rural poor into Self Help Groups (SHGs) through the process of social mobilisation, their training and capacity building and provision of income generating assets. The rural poor such as those with land, landless labour, educated unemployed, rural artisans and disabled are covered under the Scheme.

As per the Highlights of the SHG- Bank linkage programme data of 2013-14 shows, nearly $84 \%$ of all SHGs linked to banks are all women SHGs and this continues to show steady increase every year [8]. With the various agencies actively promoting women SHGs and getting them linked with Banks, women SHG movement has become the flag-bearer of the women empowerment in India. The savings harnessed by SHGs has increased by an impressive $21 \%$ over the previous year. Active participation of women in SHG-BLP has earned many laurels for the country and is often cited as a distinguishing feature of microfinance initiatives in India [8].

\section{PROGRESS OF THE SHG CREDIT BANK LiNKAGE PROGRAMME}

Highlights of the SHG-Bank Linkage Programme 2013-14

\begin{tabular}{|c|c|c|c|}
\hline \multirow[b]{2}{*}{$\begin{array}{l}\text { Sr. } \\
\text { No. }\end{array}$} & \multirow[b]{2}{*}{ Particulars } & \multicolumn{2}{|c|}{ Achievements } \\
\hline & & $\begin{array}{c}\text { Physical } \\
\text { (No. in lakh) }\end{array}$ & $\begin{array}{l}\text { Financial } \\
\text { ( } ₹ \text { in crore) }\end{array}$ \\
\hline 1 & Total number of SHGs saving linked with banks & 74.30 & 9897.42 \\
\hline (i) & Out of total (of which) exclusive Women SHGs & 62.52 & 8012.89 \\
\hline (ii) & Out of total (of which) SHGs under NRLM/SGSY/Other Govt. spons. programmes & 22.62 & 2477.58 \\
\hline 2 & Total number of SHGs credit linked during 2013-14 & 13.66 & 24017.36 \\
\hline (i) & Out of total (of which) exclusive Women SHGs & 11.52 & 21037.97 \\
\hline (ii) & Out of total (of which) SHGs under NRLM/SGSY/Other Govt. spons. programmes & 2.26 & 3480.60 \\
\hline 3 & Total number of SHGs having loans outstanding as on 31 March 2014 & 41.97 & 42927.52 \\
\hline (i) & Out of total (of which) exclusive Women SHGs & 34.06 & 36151.58 \\
\hline (ii) & Out of total (of which) SHGs under NRLM/SGSY/Other Govt. spons. programmes & 13.07 & 10177.42 \\
\hline 4 & Average loan amount outstanding/SHG as on March 2014 (in ₹.) & & 102273.21 \\
\hline 5 & Average loan amount disbursed/SHG during 2013-14 (in ₹.) * & & 175768.36 \\
\hline 6 & Estimated number of families covered up to 31 March 2014 & 97 million & \\
\hline
\end{tabular}

Fig. 1. Highlights of the SHG-Bank Linkage Programme 2013-14.

\begin{tabular}{|c|c|c|c|c|c|c|c|}
\hline \multicolumn{8}{|c|}{ Overall Progress under SHG-Bank Linkage for last 3 years } \\
\hline \multirow{2}{*}{\multicolumn{2}{|c|}{ Particulars }} & \multicolumn{2}{|c|}{ 2011-12 } & \multicolumn{2}{|c|}{ 2012-13 } & \multicolumn{2}{|c|}{ 2013-14 } \\
\hline & & $\begin{array}{c}\text { No. of SHGs } \\
\text { (lakh) }\end{array}$ & Amount & $\begin{array}{c}\begin{array}{c}\text { No. of SHGs } \\
\text { (lakh) }\end{array} \\
\text { (lakn }\end{array}$ & Amount & $\begin{array}{c}\text { No. of SHGs } \\
\text { (lakh) }\end{array}$ & Amount \\
\hline \multirow{5}{*}{$\begin{array}{l}\text { SHG } \\
\text { Savings } \\
\text { with Banks } \\
\text { as on 31st } \\
\text { March }\end{array}$} & Total SHGs & $\begin{array}{l}79.60 \\
(6.7 \%) \\
\end{array}$ & $\begin{array}{l}6551.41 \\
(-6.7 \%) \\
\end{array}$ & $\begin{array}{c}73.18 \\
(-8.1 \%)\end{array}$ & $\begin{array}{l}8217.25 \\
(25.4 \%)\end{array}$ & \begin{tabular}{|c|}
74.30 \\
$(1.53 \%)$ \\
\end{tabular} & \begin{tabular}{|l|}
9897.42 \\
$(20.45 \%)$ \\
\end{tabular} \\
\hline & $\begin{array}{l}\text { Of which NRLM/ } \\
\text { SGSY/ Other Govt. } \\
\text { spons. programmes }\end{array}$ & $\begin{array}{l}21.23 \\
(5.0 \%)\end{array}$ & $\begin{array}{l}1395.25 \\
(-23.2 \%)\end{array}$ & $\begin{array}{c}20.47 \\
(-3.6 \%)\end{array}$ & $\begin{array}{l}1821.65 \\
(30.6 \%)\end{array}$ & $\begin{array}{c}22.62 \\
(10.46 \%)\end{array}$ & \begin{tabular}{|l}
2477.58 \\
$(36.01 \%)$
\end{tabular} \\
\hline & \begin{tabular}{|l|}
$\%$ of NRLM $/ \mathrm{SGSY} /$ \\
Other Govt. spons. \\
programme Groups \\
to Total
\end{tabular} & 26.7 & 21.3 & 28.0 & 22.2 & 30.45 & 25.03 \\
\hline & All women SHGs & $\begin{array}{l}62.99 \\
(3.3 \%) \\
\end{array}$ & $\begin{array}{l}5104.33 \\
(-3.7 \%)\end{array}$ & $\begin{array}{c}59.38 \\
(-5.7 \%)\end{array}$ & $\begin{array}{l}6514.86 \\
(27.6 \%)\end{array}$ & $\begin{array}{c}62.52 \\
(5.27 \%)\end{array}$ & \begin{tabular}{|l|}
8012.89 \\
$(22.99 \%)$ \\
\end{tabular} \\
\hline & $\begin{array}{l}\text { Percentage of } \\
\text { Women Groups }\end{array}$ & 79.1 & 77.9 & 81.1 & 79.3 & 84.15 & 80.96 \\
\hline
\end{tabular}

Fig. 2. Overall Progress under SHG-Bank Linkage for Last 3 years.

The number of SHGs having loans outstanding against them from banks declined by 5.71\% (41.97 lakh as against 
44.51 lakh in 2012-13) [9].

Although the decline in the number of SHGs savings linked with Banks noticed during 201213 has been reversed during the year 2013-14 with a marginal increase of less than $2 \%[9]$.

The number of SHGs being extended fresh loans by banks increased by over $12 \%$ - nearly double the increase reported during the previous year indicating an increased confidence of banks in extending finance to existing SHGs [9].

Overall Progress under SHG-Bank Linkage for last 3 years

(Amount ₹ in crore/ Numbers in lakhs)

\begin{tabular}{|c|c|c|c|c|c|c|c|}
\hline \multirow{2}{*}{\multicolumn{2}{|c|}{ Particulars }} & \multicolumn{2}{|c|}{ 2011-12 } & \multicolumn{2}{|c|}{ 2012-13 } & \multicolumn{2}{|c|}{ 2013-14 } \\
\hline & & \multirow{2}{*}{\begin{tabular}{|c|}
$\begin{array}{c}\text { No. of SHGs } \\
\text { (lakh) }\end{array}$ \\
11.48 \\
$(-4 \%)$ \\
\end{tabular}} & \multirow{2}{*}{$\begin{array}{c}\text { Amount } \\
16534.77 \\
(13.7 \%) \\
\end{array}$} & \multirow{2}{*}{\begin{tabular}{|c|}
$\begin{array}{c}\text { No. of SHGs } \\
\text { (lakh) }\end{array}$ \\
12.20 \\
$(6.3 \%)$ \\
\end{tabular}} & \multirow{2}{*}{\begin{tabular}{|c|} 
Amount \\
20585.36 \\
$(24.5 \%)$ \\
\end{tabular}} & \multirow{2}{*}{\begin{tabular}{|c|}
$\begin{array}{c}\text { No. of SHGs } \\
\text { (lakh) }\end{array}$ \\
$\begin{array}{c}13.66 \\
(12.02 \%)\end{array}$ \\
\end{tabular}} & \multirow{2}{*}{\begin{tabular}{|l|} 
Amount \\
24017.3 \\
$(16.67 \%$ \\
\end{tabular}} \\
\hline \multirow{5}{*}{$\begin{array}{l}\text { Loans } \\
\text { Disbursed } \\
\text { to SHGs } \\
\text { during the } \\
\text { year }\end{array}$} & Total SHGs & & & & & & \\
\hline & $\begin{array}{l}\text { Of which NRLM/ } \\
\text { SGSY/ Other Govt. } \\
\text { spons. programmes }\end{array}$ & $\begin{array}{c}2.10 \\
(-12.9 \%)\end{array}$ & $\begin{array}{c}2643.56 \\
(6.6 \%)\end{array}$ & $\begin{array}{c}1.81 \\
(-13.8 \%)\end{array}$ & $\begin{array}{l}2207.47 \\
(-16.5 \%)\end{array}$ & $\begin{array}{c}2.26 \\
(24.56 \%)\end{array}$ & $\begin{array}{l}3480.60 \\
(57.67 \%)\end{array}$ \\
\hline & $\begin{array}{l}\text { \% of NRLM/SGSY/ } \\
\text { Other Govt. spons. } \\
\text { prorgramme Groups } \\
\text { to Total }\end{array}$ & 18.3 & 16.0 & 14.8 & 10.7 & 16.52 & 14.49 \\
\hline & All Women SHGs & $\begin{array}{c}9.23 \\
(-9.2 \%)\end{array}$ & $\begin{array}{c}14132.02 \\
(12.0 \%)\end{array}$ & $\begin{array}{c}10.37 \\
(12.4 \%)\end{array}$ & $\begin{array}{c}17854.31 \\
(26.3 \%)\end{array}$ & $\begin{array}{c}11.52 \\
(11.02 \%)\end{array}$ & \begin{tabular}{|l|}
21037.97 \\
$(17.83 \%)$
\end{tabular} \\
\hline & $\begin{array}{l}\text { Percentage of } \\
\text { Women Groups }\end{array}$ & 80.4 & 85.5 & 85.1 & 86.7 & 84.3 & 87.6 \\
\hline
\end{tabular}

Fig. 3. Overall Progress under SHG-Bank Linkage for Last 3 years.

The quantum of fresh loans extended to SHGs also showed an increase of nearly $17 \%$ during the year. This approach is expected to facilitate sustained financial inclusion by extending banking services to women members of SHGs, promote sustainable livelihood opportunities to the members and facilitate effective implementation of other social development programmes for women through SHGs [9].

However, working with multiple partners to accelerate progress is needed in India's progress towards Financial Inclusion. All those championing financial inclusion in India and part of its ecosystem such as financial institutions, regulatory authorities, non financial institutions, MNCs, technology giants with vested interests in the economy will need to participate.

Taking queue from success of self-help groups in effecting change, these institutions should work together in generating more such creative initiatives in a coordinated effort.

\section{OTHER INITIATIVES OF INDIAN GOVERNMENT}

As was the case of, The Pradhan Mantri Jan Dhan Yojana (PMJDY) schemes, the biggest financial inclusion initiative in the world. A year after the scheme was implemented across India; its success has highlighted the enormous role that financial inclusion programmes can play in the growth of the economy. At present, more than 17.5 crore bank accounts have been opened under the initiative and people have deposited more than Rs 22,000 crore in them. PMJDY is enabling citizens at the grassroots to perform financial transactions and keep their hard-earned money safe.

While Banks are the most effective way towards financial upliftment, India's concern of financial inclusion is gargantuan. Hence, we need to move beyond just bank account and government schemes and also rope in other non banking institutions to mobilize money.

We need to implement ad hoc initiatives along long term plans in operation.

\section{NEED FOR ALTERNATE SOURCES}

Recent news articles have highlighted the 6 richest Temples in India. These temples hold approximately Rs. 500 crore to Rs.1 lakh crore of unaccounted wealth. Each temple holds more than our Union Governments' annual budget. This is in the form of money, gold and precious stones. It has been argued that this accumulated wealth is even more than the black money stashed away in foreign banks outside India [10]. Since the contributions to such temples are from the masses, it is the moral responsibility to return the same back to the people for their upliftment.

Taking the example of Baba Ramdev and the Patanjali enterprise in India, the temple authorities can be encouraged to mobilize the stagnant wealth and invest in SHGs and other such initiatives for empowering the weaker section of society and women in particular.

Such organizations can afford to provide the seed money to new initiatives of public welfare. As such an investment is not profit motivated; a percentage of failure is expected. But if we see the glass as half full and the investment leading to some successful entrepreneurs, we can be assured that we are on the right track. Funding such initiatives should not be done only by the government or the banks as it will limit the momentum of implementation. Banks, being a profit oriented business, should not be the only torch bearers in improvement and upliftment of society there should be more participants shouldering the responsibility.

Apart from ad hoc methods, we also need to look at long term solutions.

Indian government traditionally follows the 'panch varshiya yojnas' or the 5 year Plans which does look at the problem with a long term solution. The latest example of the traffic issue in Delhi highlights our knee-jerk approach to a problem. In 2003, the Madhya Pradesh state government launched the 'Head start' computer scheme, which was a computer-enabled programme under the Rajiv Gandhi Shiksha Mission, using multimedia-based lessons to enhance classroom teaching. But neither the computers are functioning nor are teachers trained to operate them. The government also installed 42-inch screens and provided a laptop to 1,450 government schools across the state under the programme. The government spent crores of rupees on the schemes, yet the results have been far from satisfactory.

We still seek a coordinated multi pronged approach that keeps up with the growth of population in our country. In doing so we need all avenues to contribute which are the banking as well as non banking channels. Only then can we reach the breakeven point of the problem and possibly surpass it.

The story of how Japan keeps a defunct train station running for just one regular passenger is noteworthy. Though the railway authority wanted to stop this unprofitable route, the government decided to continue it for that one passenger who was a college going girl. The train is set to be stopped after the girl has completed her graduation. This commitment to the cause is what is needed to create an environment of growth and development.

\section{WOMEN EMPOWERMENT - A GLOBAL NECESSITY}

The empowerment of women has become one of the most 
important concerns of $21^{\text {st }}$ century not only at national level but also at the international level. Government initiatives alone would not be sufficient to achieve this goal. Society must take initiative to create a climate in which there is no gender discrimination and women have full opportunities of self decision making and participating in social, political and economic life of the country with a sense of equality. Uplifting of women assures uplifting of the entire family. For every woman who is empowered, the quality of life is improved of the entire family. If we need to radically change the quality of life of women, we need to fast pace the process. Else, we will not even reach the breakeven point of the matter.

A R Nanda, executive director of Population Foundation of India has pointed out, "population growth can't be controlled by coercive measures (but) with economic growth, education for all and most importantly empowerment of women." The best way of empowerment is perhaps through inducting women in the mainstream of development. Women empowerment will be real and effective only when they are endowed income, property and knowledge so that they may stand on their feet and build up their identity in the society.

As we say, "When women move forward the family moves, the village moves and the nation moves".

\section{CONCLUSION}

The scheme of SHG is a good platform to build a better future for the rural masses. However, working with multiple partners to accelerate progress is needed toward India's journey of Financial Inclusion. All those Championing Financial Inclusion, MNCs, technology giants with vested interest in the economy will need to participate and work together in generating more such creative initiatives with more coordination.

\section{REFERENCES}

[1] Gender and Rural Employment Policy, Brief \#1, Naoko Otobe (ILO), p. 1, 2010.

[2] Sos childrens villages, UK. (Sep 04, 2013). [Online]. Available: http://www.soschildrensvillages.org.uk/news/international-literacy-da y/thirty-nine-percent-of-the-worlds-illiterate-adults-are-found-in-india

[3] Government of India, Ministry of Human Resource Development Bureau of Planning, Monitoring and Statistics, New Delhi, p. 17, 2014

[4] The Hindu. (July 17, 2013). [Online]. Available: http://www.thehindu.com/news/national/other-states/around-260-m-lit erate-people-in-india-cannot-read-says-study/article4921075.ece

[5] Report of the Committee on Financial Inclusion, January 2008 as per the Government of India (GoI) vide order no. 6/5/2006/AC dated 22 Chapter 7, June 2006.

[6] NABARD Annual Report, 2013, p. 144.

[7] Master Circular on Priority Sector Lending-Special Programmes SGSY, RBI circular, July 2011.

[8] P. Murthy, Economic Empowerment of Rural Women by Self Help Group through Micro Credit, December 22, 2012.

[9] Status of Microfinance in India, NABARD report 2013-14

[10] Indiamarks.

[Online].

Available:

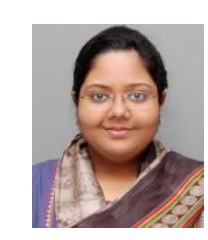

Sonjuhi Akhil Succena was born in Ahmedabad Gujarat, India on June 19, 1989. Sonjuhi has a B.com degree from Gujarat University in 2010. She has done the master of business administration in banking and finance from Manipal University, Bengaluru.

She has been participating in debates and has won many awards at university and state level. Her short film 'What if...' made on gender bias in India won the First prize at National Level. Currently she is working in Ahmedabad as a regional risk manager in the $2^{\text {nd }}$ largest Bank in India. 